\title{
Congenital Plasmodium vivax Malaria in a Non-Endemic Country; A Unique Case in the Netherlands
}

\author{
Rutgers $\mathrm{MM}^{1}{ }^{*}$, Clemens $\mathrm{SCM}^{1}$, de Winter JP1 ${ }^{1}$, Sloot SC ${ }^{1}$, Jager $\mathrm{MM}^{2}$ and Mank TG ${ }^{2}$ \\ ${ }^{1}$ Spaarne Gasthuis, Hoofddorp, Netherlands \\ ${ }^{2}$ Regional Laboratory for Medical Micriobiology \& Public Health, Haarlem, Netherlands \\ *Corresponding author: Rutgers MM, Spaarne Gasthuis Academics, Hoofddorp, Netherlands, Tel: Tel: 023-2240000; E-mail: \\ tijs_rutgers@hotmail.com
}

Received date: November 10, 2016; Accepted date: January 04, 2017; Published date: January 09, 2017

Citation: Rutgers MM, Clemens SCM, de Winter JP, Sloot SC, Jager MM, et al. (2017) Congenital Plasmodium vivax Malaria in a Non-Endemic Country; A Unique Case in the Netherlands. Pediatric Infect Dis 2:33. doi: 10.21767/2573-0282.100033

Copyright: (C) 2017, Rutgers MM, et al. This is an open-access article distributed under the terms of the Creative Commons Attribution License, which permits unrestricted use, distribution, and reproduction in any medium, provided the original author and source are credited.

\section{Abstract \\ Congenital malaria is a rare complication of Plasmodium infection during pregnancy. We present a case of a neonate with a mother who migrated from an endemic area. The mother developed fever during delivery due to Plasmodium vivax infection. Despite postnatal negative screening for malaria, the neonate developed fever on day 20 and was diagnosed with Plasmodium vivax malaria. The neonate was successfully treated with chloroquine. Follow-up including repeated malaria screening might have spared the neonate a period of illness with consecutive chances of complications.}

\section{Introduction}

A common clinical problem encountered in emergency departments is an infant with fever. Neonates with temperature above $38.0{ }^{\circ} \mathrm{C}$ require comprehensive diagnostic evaluations including blood, urine, and cerebrospinal fluid cultures [1]. Viral and rare parasitic infections should be considered when evaluating febrile neonates, too. It is of utmost importance to obtain, geographical and other demographic information. The incidence of malaria in the Netherlands is 150-300 cases annually. The Netherlands is considered a non-endemic country for malaria, thus these cases are travel-related. Driessen et al. [2] reported a total incidence of paediatric malaria in the Netherlands of 32 patients in 20 months. The most predominant parasite was Plasmodium falciparum (81\%), and infections were mainly acquired in sub-Saharan Africa. Congenital malaria, defined as mother-to-child transmission of Plasmodium parasites, is a rare complication of malaria infection during pregnancy in endemic areas. An estimation of the prevalence of congenital malaria is complicated; in endemic areas it is difficult to differentiate between neonatal and congenital malaria [3]. Prevalence is region dependent; differing from $0.03 \%$ to $46.7 \%$ [3]. A literature search revealed 8 documented cases of congenital malaria in European countries [4-10], as summarized in Table 1. Congenital malaria has never been documented in the Netherlands previously.

Table 1: Summary of documented congenital malaria cases in Europe, ${ }^{*}$ interval since last stay in endemic area and pregnancy; ${ }^{* *}$ Urinary Tract Infection

\begin{tabular}{|c|c|c|c|c|c|c|c|}
\hline Authors & $\begin{array}{l}\text { Endemic area + } \\
\text { interval }^{*}\end{array}$ & $\begin{array}{l}\text { Symptoms in } \\
\text { mother }\end{array}$ & $\begin{array}{l}\text { Age of } \\
\text { diagnosis/sex }\end{array}$ & Parasite & Treatment & Outcome & Profylaxis \\
\hline $\begin{array}{l}\text { de Pontual et } \\
\text { al. }\end{array}$ & Congo, 2 years & None & 6 weeks/ female & P. malariae & $\begin{array}{l}\text { Oral chloroquine } \\
\text { Bloodtransfusion }\end{array}$ & $\begin{array}{l}\text { Complete } \\
\text { recovery }\end{array}$ & None \\
\hline \multirow{2}{*}{ Zenz et al. } & \multirow{2}{*}{ Ghana, 1.5 years } & \multirow{2}{*}{ None } & \multirow{2}{*}{8 weeks/ male } & P. falciparum & \multirow{2}{*}{$\begin{array}{l}\text { Oral quinine } \\
\text { hydrochloride }\end{array}$} & \multirow{2}{*}{$\begin{array}{l}\text { Complete } \\
\text { recovery }\end{array}$} & \multirow{2}{*}{ None } \\
\hline & & & & P. malariae & & & \\
\hline \multirow{2}{*}{ Prior et al. } & India & \multirow{2}{*}{$\begin{array}{lr}\text { Fever } & \text { during } \\
\text { pregnancy } & \text { no } \\
\text { treatment } & \end{array}$} & \multirow{2}{*}{26 days/ female } & \multirow{2}{*}{$P$. vivax } & \multirow{2}{*}{$\begin{array}{l}\text { Intravenous quinine } \\
\text { Bloodtransfusion }\end{array}$} & \multirow{2}{*}{$\begin{array}{l}\text { Complete } \\
\text { recovery }\end{array}$} & \multirow{2}{*}{ None } \\
\hline & 5-7 months & & & & & & \\
\hline Del Punta et al. & $\begin{array}{l}\text { Pakistan, months } \\
\text { before pregnancy }\end{array}$ & $\begin{array}{l}\text { Fever during } \\
\text { pregnancy } \\
\text { treated as } \mathrm{UTI}^{* *}\end{array}$ & 22 days/ female & $P$. vivax & Oral chloroquine & $\begin{array}{l}\text { Complete } \\
\text { recovery }\end{array}$ & None \\
\hline
\end{tabular}




\begin{tabular}{|c|c|c|c|c|c|c|c|}
\hline Comellini et al. & Congo & $\begin{array}{l}\text { Malaria in week } \\
\text { of delivery }\end{array}$ & 21 days & P. vivax & $\begin{array}{l}\text { Oral quinine } \\
\text { hydrochloride }\end{array}$ & $\begin{array}{l}\text { Complete } \\
\text { recovery }\end{array}$ & None \\
\hline Vottier et al. & $\begin{array}{l}\text { Guyana, } 6 \text { months } \\
\text { before pregnancy }\end{array}$ & $\begin{array}{l}\text { Malaria during } \\
\text { pregnancy } \\
\text { treated }\end{array}$ & 21 days/ female & $P$. vivax & Oral chloroquine & $\begin{array}{l}\text { Complete } \\
\text { recovery }\end{array}$ & None \\
\hline Vottier et al. & Angola, 3 years & None & 19 days/ female & P. ovale & Oral chloroquine & $\begin{array}{l}\text { Complete } \\
\text { recovery }\end{array}$ & None \\
\hline Romero et al. & $\begin{array}{l}\text { Ecuatorial Guinea, } \\
1 \text { month }\end{array}$ & None & 3 weeks/female & P. falciparum & Oral mefloquine & $\begin{array}{l}\text { Complete } \\
\text { recovery }\end{array}$ & None \\
\hline
\end{tabular}

\section{Case Report}

Upon presentation at the emergency clinic at the age of 20 days, an irritable febrile male neonate was seen. This child was born at term from a mother who resided in Eritrea. The parents emigrated from Eritrea ten months before birth. During the year prior to pregnancy the mother was treated for malaria (Plasmodium species and medication unknown) in a refugee camp in Ethiopia. At our hospital in the Netherlands she gave birth to a healthy boy, with a birth weight above the $50^{\text {th }}$ percentile (gestational age $41+3$, birth weight $3970 \mathrm{gm}$ ). The mother tested previously HIV negative. During labour the mother developed fever; based on Plasmodium vivax infection, diagnosed in peripheral blood smear (Figure 1), and real timePCR confirmed. In our laboratory malaria screening comprises microscopic examination of Giemsa-stained thin and thick blood smears, a Quantitative Buffy Coat Analysis (QBC) and the Binax Now Malaria test. In addition, Plasmodium species specific PCR can be performed. The detection limit of the thick blood smear in our laboratory is determined as 5-10 parasites/ $\mu$ l blood, for QBC 0.5-1 parasites/ $\mu$ l blood. Although the detection limit of the PCR is not yet determined, it can be assumed to be even lower then 0.5-1 parasites/ $\mu$ l blood. Due to maternal infection the neonate was tested for malaria on the first day of life; the screening was negative (PCR confirmed). During follow-up one week post-partum no symptoms of malaria were noticed; a malaria screening was not performed. After that, the child was discharged from outpatient monitoring. The mother was successfully treated with chloroquine and primaquine.

Two weeks later the neonate developed fever and was presented at the emergency clinic. The child had a temperature of $38.9{ }^{\circ} \mathrm{C}$ with normal heart rate and respiratory frequency. Auscultation of heart and lungs showed no abnormalities. No hepatosplenomegaly was present. A sepsis workup was performed including blood- and urine culture, and a microscopic examination of the urine sediment. Because of maternal malaria infection, malaria screening of the neonate was included. Complete Blood Count revealed a hemoglobin of $13.3 \mathrm{~g} / \mathrm{dL}$, leucocytes of $7.310^{\wedge} 9 \mathrm{~g} / \mathrm{L}$, thrombocytopenia $2710^{\wedge} 9 \mathrm{~g} / \mathrm{L}$, and an increased C-Reactive Protein of $90 \mathrm{mg} / \mathrm{L}$. Malaria screening revealed trofozoites (Figure 2) and schizonts of Plasmodium vivax, with a parasite load of $0.4 \%$ (equivalent to approximately $1610^{\wedge} 3$ parasites/ul blood). Due to proven malaria infection, lumbar puncture was not performed. The patient was admitted to the paediatric department and treated with oral chloroquine for 3 days. Fever and irritability disappeared after initiation of treatment. He was discharged in good clinical condition after 5 days. At outpatient follow up two weeks after discharge, the baby was in good condition; malaria screening was negative.

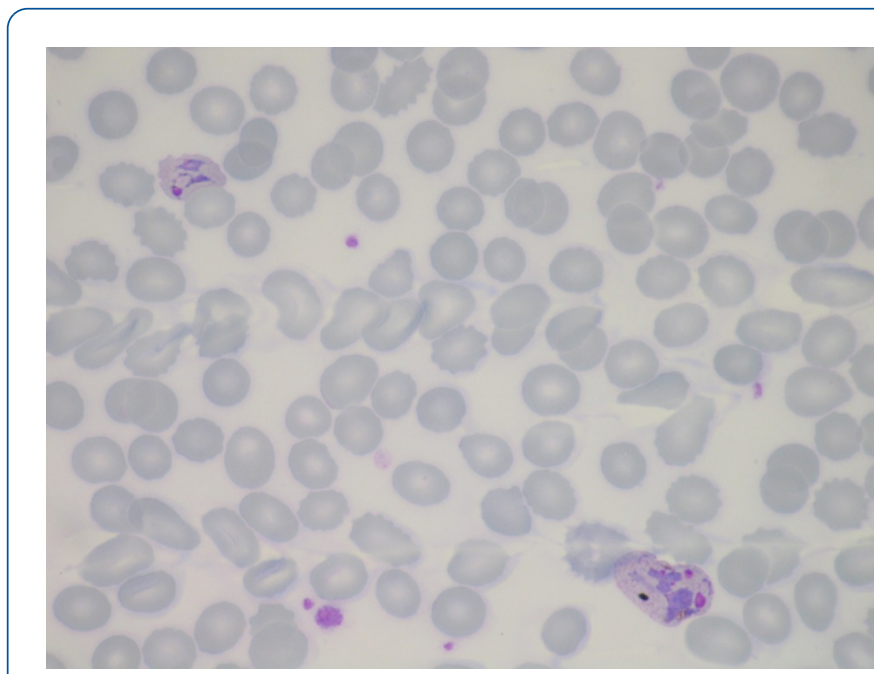

Figure 1: Two enlarged erythrocytes infected with trofozoites which is consistent with Plasmodium vivax morphology [Giemsa stained thin blood smear from mother of newborn; blood sample taken during labour (Magnification $x$ 1000)].



Figure 2: Three enlarged erythrocytes infected with trofozoites which is consistent with Plasmodium vivax morphology [Giemsa stained thin blood smear from 20 day old neonate (Magnification $x$ 1000)]. 


\section{Discussion}

The case presented describes a neonate with proven congenital malaria infection with Plasmodium vivax, to our knowledge, the first case in the Netherlands. In non-endemic areas diagnosis can only be made if malaria is included in the differential diagnosis of neonatal fever. Although prevalence in literature vary greatly as noted before, pregnant women in high endemic areas have antibodies possibly decreasing transplacental transmission [3]. Migration from high to nonendemic areas, as described in this case, with subsequent loss of immunity due to lack of exposure, could increase the risk of overt malaria in pregnant women and subsequent congenital transmission of parasites. Additionally, pregnancy can provoke activation of the dormant liver stages (hypnozoites), where maternal tertian malaria was not additionally treated with primaquine.

Congenital infection with malaria may occur in all species, but is most commonly associated with Plasmodium falciparum and Plasmodium vivax [3]. Congenital malaria can present with fever, feeding problems, vomiting, diarrhoea and irritability in neonates. The symptoms typically appear between day 10 and 30 after delivery [3]. Blood investigation may reveal anaemia, thrombocytopenia and hyperbilirubinemia. According to the WHO guideline on the treatment of uncomplicated chloroquinesensitive Plasmodium vivax infections, neonates can be treated with chloroquine. In cases of transplacental infection, additional treatment with primaquine is not mandatory. Prophylaxis for neonates at risk of congenital malaria is not described in literature.

In retrospect, malaria serology performed on the $12^{\text {th }}$ week pregnancy serum of the mother appeared to be positive; antibodies against the pan malaria antigen could be detected. PCR's specific for Plasmodium falciparum, Plasmodium malariae, Plasmodium ovale and Plasmodium vivax performed on the serum did not detect DNA of either of the Plasmodium species. Malaria PCR's in the blood of the neonate at the first day of life were also negative. We hypotheses that in this particular case with a healthy neonate, with a birth weight on the $50^{\text {th }}$ percentile and negative malaria screening, very little Plasmodium vivax infected erythrocytes were transferred from mother to child during delivery. Unfortunately umbilical cord blood was not available for PCR testing. After initial negative malaria screening, we assumed mother-to-child transmission of parasites during pregnancy to be excluded.

In retrospect, we recommend repeated malaria screening during weekly outpatient follow-up visits for the first month of life in neonates with symptomatic mothers and in neonates with symptoms. It is hard to identify clear risk factors in neonates.
Many women from endemic countries have parasites in their blood without symptoms of malaria. Repeated malaria screening is recommended because of incubation time and possible false negative results. The final outcome with current policy has had no major consequences for the neonate. In general, Plasmodium vivax infection is not severe and mortality is very low. However, complications like severe anaemia and haemorrhage must always be taken into account in younger children. Given the increase of migration from, and tourism to, tropical destinations, malaria is a differential diagnosis in neonates with sepsis or fever of unknown origin in non-endemic areas. In case of initial negative malaria screening, screening should be repeated. Although modern techniques in malaria diagnosis are highly sensitive and specific, a single negative test result still does not exclude malaria infection.

\section{References}

1. Hagmann S, Khanna K, Niazi M, Purswani M, Robins EB (2007) Congenital malaria, an important differential diagnosis to consider when evaluating febrile infants of immigrant mothers. Pediatric Emergency Care 23: 326-329.

2. Driessen GJ, Pereira RR, Brabin BJ, Hartwig NG (2008) Imported malaria in children: a national surveillance in the Netherlands and a review of European studies. Eur J Public Health 18:184-188.

3. Lesko CR, Arguin PM, Newman RD (2007) Congenital malaria in the United States: a review of cases from 1966 to 2005. Arch Pediatr Adolesc Med 161:1062-1067.

4. De Pontual L, Poilane I, Ledeur F, Haouchine D, Lachassinne E, et al. Report of a case of congenital malaria Plasmodium malariae in France. J Trop Pediatr 52: 448-450.

5. Zenz W, Trop M, Kollaritsch H, Reinthaler F (2000) Congenital malaria due to Plasmodium falciparum and Plasmodium malariae. Wien Klin Wochenschr 112: 459-461.

6. Prior AR, Prata F, Mouzinho A, Marques JG (2012) Congenital malaria in a European country. BMJ Case Rep 12: 2012

7. Del Punta V, Gulletta M, Matteelli A, Spinoni V, Regazzoli A, et al. (2010) Congenital Plasmodium vivax malaria mimicking neonatal sepsis: a case report. Malar J Mar 9: 63.

8. Comellini L, Tozzola A, Baldi F, Brusa S, Serra L, et al. (1998) Plasmodium vivax congenital malaria in a newborn of a Zairian immigrant. Ann Trop Paediatr 18: 41-43.

9. Vottier G, Arsac M, Farnoux C, Mariani-Kurkdjian P, Baud O, et al. (2008) Congenital malaria in neonates: two case reports and review of the literature. Acta Paediatr 97: 505-508.

10. Romero Urbano JM, Vázquez López R, Jurado Ortiz A, Martínez Valverde A (2000) A case of neonatal malaria in Spain. An Esp Pediatr 52: 377-380. 